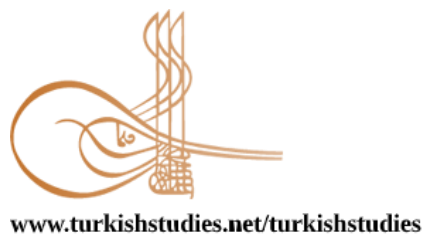

Turkish Studies

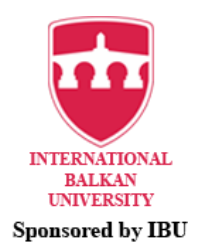

Research Article / Araştırma Makalesi

\title{
Pandemi Dönemi Eğitim: Sorunlar ve Fırsatlar
}

Education in the Pandemic Period: Challenges and Opportunities

\author{
Tamer Sar1 ${ }^{*}$ - Funda Nayır ${ }^{* *}$
}

\begin{abstract}
Although the Covid-19 pandemic period causes challenges in education, revising the education systems should be considered as an opportunity to update the methods that have diverged from its basic philosophy and whose validity is discussed. The aim of this study is to examine the pandemic period in terms of education in international reports, to identify the emerging challenges and the opportunities created by this process. Basic research, one of the qualitative research methods, was used in the study. Within the scope of the research, educational reports published by the Organisation for Economic Co-operation and Development (OECD, 2020b), United Nations Educational, Scientific and Cultural Organization (UNESCO, 2020), and the World Bank (2020) were examined. In the reports, the themes related to the challenges arising during the epidemic period were gathered under the topics related to the learning-teaching process, the challenges arising from stakeholders, technological problems, health problems and other topics. In addition, the themes related to the opportunities that emerged during the epidemic were collected under the titles of schools' function, new education perception, alternative education structures, 21st century teaching and learning skills, parent participation and school management skills. As a result, even though the Covid19 pandemic process brings problems in terms of education, these challenges created new opportunities. Challenges related to the learningteaching process, problems arising from stakeholders and health problems rethinking the function of schools, creating an opportunity for alternative education structures with the emerging new perception of education. Similarly, technological problems, problems related to the learning-teaching process, and problems arising from stakeholders also provide opportunities for developing schools' function, new education perception, alternative education structures, 21st-century teacher and learner skills, parent participation, and school management skills.
\end{abstract}

\section{Structured Abstract: Introduction}

In addition to the challenges experienced in education, the Covid-19 pandemic period can be seen as an opportunity to revise the education, to update the methods that have diverged from its basic philosophy and are discussed in many respects. In order to determine these methods, examining the reports prepared from different perspectives can start a solution process. In addition, this epidemic may have provided an opportunity to transform educational policies into a more inclusive and fair structure at a time when the whole world has

\footnotetext{
* Öğr. Gör. Dr, Pamukkale Üniversitesi, Yabancı Diller Yüksekokulu, Temel Yabancı Diller Bölümü Instructor Dr, Pamukkale University, School of Foreign Languages, Department of Basic Foreign Languages ORCID 0000-0003-3752-9277

tamersari@pau.edu.tr

*** Doç. Dr., Pamukkale Üniversitesi, Eğitim Fakültesi, Eğitim Bilimleri Bölümü

Assoc. Prof., Pamukkale University, Educational Faculty, Departmant of Educational Sciences ORCID 0000-0002-9313-4942

fnayir@pau.edu.tr

Cite as/ Atıf: Sarı, T., Nayır, F. (2020). Pandemi dönemi eğitim: sorunlar ve firsatlar. Turkish Studies, 15(4), 959-975.

https://dx.doi.org/10.7827/TurkishStudies.44335

Received/Geliş: 18 June/Haziran 2020

Accepted/Kabul: 10 August/Ağustos 2020

Copyright $\mathbb{C}$ MDE, Turkey

Checked by plagiarism software

Published/Yayın: 30 August/Ağustos 2020

CC BY-NC 4.0
} 
drawn attention to education systems. Health, education and employment are among the most striking issues during the epidemic period (Buheji \& Ahmed, 2020). In terms of education, it can be stated that this period should be evaluated as an opportunity by both policy makers and education leaders.

It is important to examine international reports in order to establish a more comprehensive idea in order to determine the experiences and proposed opportunities obtained worldwide. In the international reports examined in this context, revealing the challenges experienced in education during the pandemic period and the opportunities brought by these challenges may contribute to a better understanding of the post-pandemic education process. The aim of this study is to examine the pandemic period in terms of education and to identify the challenges that arise and the opportunities created by this process. For this purpose, answers to the following questions have been sought:

1. What are the challenges experienced in education during the pandemic process?

2. What are the educational opportunities created by the challenges experienced in education during the pandemic?

\section{Method}

In this study, the challenges and opportunities of the pandemic period were examined in terms of Education. Basic research, one of the qualitative research methods, was used in the study. Basic research is research that produces information for knowledge and aims to reach the reality related to that phenomenon while researching a case (Patton, 2014). Within the scope of the research, educational reports published by the Organisation for Economic Co-operation and Development (OECD, 2020b), United Nations Educational, Scientific and Cultural Organization (UNESCO, 2020), and the World Bank (2020) were examined. Sampling reports examined in terms of challenges and opportunities in education during Covid 19. The reports that emerged in the research were handled as a sub-theme of each of the challenges and opportunities, and main themes were created by combining similar challenges and opportunities.

\section{Results}

The themes related to the challenges revealed in the reports were collected under the topics of problems related to the learning-teaching process, problems arising from stakeholders, technological problems, health problems and other topics. The challenges under the theme of problems related to the learning teaching process include interruption of learning, difficulties in creating, maintaining and improving distance learning, increase in dropout rates, difficulties in measuring learning outcomes, curriculum deficiencies, inequality in attainment in education and students' learning losses. Under the theme of challenges arising from stakeholders; confusion and stress for teachers, parents and teachers caught unprepared for distance education, difficulties in communicating with parents. The theme of technological challenges consists of technological deficiencies, inability to reach technology and technological deficiencies of teachers. The theme of health challenges consists of teachers, students and parents feeling bad, students' malnutrition, more exposure to violence and exploitation and social isolation. Finally, the other challenges theme included gaps in childcare, high economic costs, schools that remained open, and increased pressure on school systems.

The themes related to the opportunities that emerged in the reports were collected under the headings of schools' function, new education perception, alternative education structures, 21st century teacher and learner skills, parent participation and school management skills. The schools' functions theme consists of rethinking future schools, reviewing the function of schools and providing healthier school conditions. The new perception of education theme consists of developing new evaluation systems, re-determining the roles of parents, teachers, mass media, government and others in the education process after the epidemic and trying to make education systems stronger and fairer. The theme of alternative education structures consists of preparing schools for the crisis period, developing distance education programs and developing new online learning platforms. Sub-themes of the 21st-century learner and teacher's skills theme included taking into account the professional development of teachers, increasing the teachers and students' skills on technology, developing the teachers' technical and pedagogical skills required to integrate digital devices into education, and expanding online learning ways to bring new skills to the unemployed in this process. The parent involvement theme included increasing parental involvement, empowering parents, strengthening school-family cooperation, and involving parents in the curriculum development phase. Finally, the theme of school management skills 
consists of developing new ways of communication, reviewing education plans, establishing student health monitoring systems in schools, and developing policies that emphasize teachers' and students' health.

\section{Discussion and conclusion}

Although the Covid 19 pandemic process brings challenges in terms of education, these problems have created new opportunities. The challenges that arise in this process are dealt with under the themes related to the learning-teaching process, problems from stakeholders, technological problems and health problems. The challenges also create opportunities for the process. Challenges related to the learning-teaching process, problems arising from stakeholders and health problems rethinking the function of schools, creating an opportunity for alternative education structures with the emerging new perception of education. Similarly, technological problems, problems related to the learning-teaching process, and problems arising from stakeholders also provide opportunities for developing schools' function, new education perception, alternative education structures, 21st-century teacher and learner skills, parent participation, and school management skills.

Keywords: Educational Sciences, Eeducational administration, Covid 19, New education, Challenges, Opportunities, 21st century learning and teaching skills

Öz: Covid-19 pandemi dönemi eğitimde sorunlar yaşanmasına neden olmakla birlikte eğitim sistemlerinin yeniden gözden geçirilmesi, temel felsefesinden uzaklaşmış ve geçerliliği tartışlan yöntemlerin güncellenmesi için bir firsat olarak değerlendirilmelidir. Bu çalışmanın amacı pandemi dönemini uluslararası raporlarda eğitim açısından inceleyerek, ortaya çıkan sorunları ve bu sürecin yaratı̆̆ı firsatları belirlemektir. Çalışmada nitel araşıırma yöntemlerinden temel araştırma kullanılmıştır. Araştırma kapsamında Ekonomik Kalkınma ve İş birliği Örgütü (OECD, 2020b), Birleşmiş Milletler Eğitim, Bilim ve Kültür Örgütü (UNESCO, 2020) ve Dünya Bankası (2020) tarafından yayınlanan eğitim raporları incelenmiş̧tir. Raporlarda ortaya çıkan sorunlara ilişkin temalar öğrenme -öğretme süreciyle ilgili sorunlar, paydaşlardan kaynaklanan sorunlar, teknolojik sorunlar, sağlık sorunları ve diğer başlıkları altında toplanmıştır. Ayrıca salgın döneminde ortaya çıkan firsatlara ilişkin temalar okulların işlevi, yeni eğitim algısı, alternatif eğitim yapılanmaları, 21.yy öğrenme öğretme becerileri, veli katılımı ve okul yönetim becerileri başlıkları altında toplanmıştır. Sonuç olarak Covid19 pandemi süreci eğitim açısından sorunlar getirmekle birlikte bu sorunlar yeni firsatlar oluşturmuştur. Öğrenme -öğretme süreciyle ilgili sorunlar, paydaşlardan kaynaklanan sorunlar ve sağlık sorunları okulların işlevini yeniden düşünmek, ortaya çıkan yeni eğitim algısıyla alternatif eğitim yapılanmalarına firsat oluşturmaktadır. Benzer şekilde teknolojik sorunlar, öğrenme -öğretme süreciyle ilgili sorunlar ve paydaşlardan kaynaklanan sorunlar da 21.yy öğrenme öğretme becerileri, veli katılımı ve okul yönetim becerilerini geliştirme açısından firsat oluşturmaktadır.

Anahtar Kelimeler: Eğitim bilimleri, Eğitim yönetimi, Covid 19, yeni eğitim, sorunlar, firsatlar, 21.yy öğrenme öğretme becerileri

\section{Giriş}

Dünya zaman zaman doğal ya da insan kaynaklı birçok felaket atlatmış ve insanoğlu bu felaketlerden ders çıkarmış, sürekli önlemlerini geliştirerek varlığını devam ettirebilmiştir. Örneğin, süper firtınalar, orman yangınları, depremler ve salgın hastalıklar dünyada insan varlığını zaman zaman tehlikeye atmıştır. Süper firtınalardan korunmak için erken uyarı sistemleri (Bowman, Rice Et A Warner, 2014) geliştirilmiş, ayrıca depremden korunmak için depreme dayanıklı yapı teknolojileri (Güler, \& Celep, 2020) geliştirilmiştir. Diğer bir ifadeyle insanoğlu yaşadığı afetlerden sürekli daha bilgili ve daha güçlü çıkmasını bilmiştir. Ayrıca son dönemlerde haberleşme kaynaklarının gelişmesi, insanların elde ettikleri ulaşım imkânları ve hızı sayesinde bu felaketlerden haberdar olmaya başlamışlar ve farklı dönemlerde farklı bölgelerde yaşansa da insanlar bu felaketlerden korunma yöntemlerini ve deneyimlerini paylaşmaya başlamışlardır. Başlangıçta önlem olarak geliştirilen bazı teknolojileri zamanla farklı felaketlere davetiye çıkarmıştır. Örneğin, ulaşım teknolojilerinin gelişmesi ve bunu getirisi olan küreselleşme sayesinde dünya vatandaşlığı kavramı 
gelişmiş ve dünyadaki insan hareketliliği son dönemde yaşanan ve Covid-19 olarak adlandırılan virüsün tüm insanları tehdit eden bir pandemi (WHO, 2020a) olmasına yol açmıştır.

Daha önce yaşanan pandemiler bu kadar yaygın hale gelmemiş, bölgesel veya kıtalarla sınırlı kalmıştır. İnsan hareketliliğinin sonucu olarak son yaşanan pandemi yayılma hızı bakımından insanoğlunu hazırlıksız yakalamış denilebilir. Yüksek öldürücülük oranına sahip pandemilerin sıklığ ortalama bir insan ömründen daha uzun zaman dilimlerinde ortaya çıktığı için insanoğlu pandemiler konusunda yeterince tecrübe biriktirememiş denilebilir. Tarihteki bu pandemiler (H1N1) 20092010/Asya Gribi 1957-1958/İspanyol Gribi 1918-1919 (WHO, 2020b) olarak siralanabilir. Ancak Covid-19 31 Aralık 2019 tarihindeki ilk tanının konulmasının ardından insan hareketliliğinin de yardımıyla hızlı bir şekilde yayılmış ve 11 Mart 2020 tarihinde Dünya sağlık örgütü tarafından pandemi olarak ilan edilmiştir (WHO, 2020b). Pandemi ile mücadelenin önemli aşamalarından birisi olarak gösterilen ilaçsız mücadele (Feng, Xu, \& Zhao, 2007) kapsamında sosyal mesafe uygulamasına geçilmiş ve bu kapsamda Dünya genelinde 102 ülkede okullar kapatılmış ve 900 milyon öğrenci (OECD, 2020a) okuldan uzak kalmıştır.

Okulda yapılan eğitime ara verilmesi başlangıçta eğitimcileri ve eğitim paydaşlarını endişeye düşürmüş ve yeni oluşan duruma uyum sürecinde bazı sorunlar yaşanmıştır. Yaşanan bu sorunların başlıca sebebi daha önce benzer bir süreç yaşanmamış olması ve tecrübe edilmemesinden kaynaklanmış olabilir. Salgın döneminde eğitimde yaşanan sorunların bilimsel yöntemlerle belirlenmesi bu tecrübe eksikliğini giderecek ve olası bir durum için yine birçok afette olduğu gibi hazırlıklı olunmasını sağlayacaktır. Örneğin, okulların salgın gerekçesi ile kapatılması sonucu uygulanan dijital öğrenme öğrencilerin öz düzenleme becerilerine sahip olmalarını gerektirir ve dürüstlük, iş ahlakı, çalışkanlık ve azim gibi kişisel özelliklerin desteklenmesi ile öz düzenleme becerisi kazandırılabilir (Huber ve Helm, 2020), dolayısıyla okulların açık olduğu dönemde öğrencilere kendi kendine öğrenme becerilerinin kazandırılması öğrencilerin öğrenme motivasyonlarını artıracağı için (Yusuf, 2011) zorunlu dönemlerde akademik öğrenmelerin sadece okul düzeyinde kalmasının önüne geçecek ve okulların üstlendikleri sorumluluğun hafiflemesine yardım edecektir. Bu sorunların belirlenmesi için birçok ülkede ulusal çerçevede araştırmalar yapılıp raporlar hazırlansa da (Buheji \& Ahmed, 2020; PHA, 2020; Saavedra, 2020; Huber ve Helm, 2020), dünya genelinde uluslararası çalışmalar yapan kurumların hazırladıkları raporlar genel durumun daha iyi anlaşılması bakımından daha geçerli raporlar olarak değerlendirilebilir. Artık geçmişten ders alarak geleceği yeniden ve daha güçlü planlama zamanı gelmiş ve kriz yönetiminin sonunda bu krizden öğrenilen tecrübeyi fırsata dönüştürecek yönetim felsefesini ve politikaları belirlemek önem kazanmıştır.

Covid-19 salgın döneminde eğitim yaşanan olumsuzluklar arasında sayılabilecek durumlar değerlendirildiğinde, önde gelen sorunların öğrenme kaybı, okulu bırakma oranlarının artması ve beslenme olarak ortaya çıktığı görülmektedir (Saavedra, 2020). Ayrıca çevrimiçi verilen eğitimlere erişmede firsat eşitsizliği olan öğrenciler (Saran, 2020) özellikle gelişmekte olan ülkelerde ortaya çıkan önemli bir sorundur. Pandemi döneminde evde kalma tedbirlerinin olumsuz bir diğer sonucu ise aile içi çocuk istismarları ile ilgili şikâyetlerde artış olmasıdır (Koh, Lee, Lo, Wong, \& Yap, 2020). Koh, ve diğerleri (2020) tarafından hazırlanan rapora göre, salgın döneminde İngiltere'de ulusal aile içi istismar yardım hattına bir hafta içinde yapılan çağrılarda \% 65'lik bir artış bildirilmiştir. Ayrıca, Singapur Mart 2020'de bir yıl öncesine göre ülke çapında şiddetin yaklaşık \% 35 oranında artış gösterdiğini rapor etmiştir. Benzer bir diğer sonuç ise ABD'de pandemiye bağlı şiddetli çocuk istismarı vakalarının sayısındaki artış olarak verilebilir.

Covid-19 salgınını döneminde yaşananların eğitim açısından değerlendirilmesinde firsat olarak ele alınabilecek konular da dikkat çekmektedir. Bunların en önemlisi politika yapıcılara COVID-19 krizinin sağladığı ve daha önceki eski kurumsal kısıtlamalara ve sistemi yavaşlatan siyasi ve idari uygulamaları yeniden düzenleme firsatıdır (Saran, 2020). Eğitim için yeni düzenlemeler 
sadece okul binalarının dezenfekte edilmesi değil aynı zamanda eğitim sisteminin de yeniden düzenlenmesi olarak değerlendirilebilir. Salgın döneminin bize kazandırdığı bir diğer firsat ise, kurum kuruluş ve bireylerin konfor alanlarından çıkarak yaşam yoğunluğu içinde üzerinde düşünme firsatı bulamadıkları tutum davranış ve alışkanlıkları gözden geçirme ve salgın sonrası yeni yaşantılarına yeni bir perspektif kazandırma şansı olarak değerlendirilebilir (Buheji \& Ahmed, 2020). Eğitim firsatları olarak ayrıca, karma öğrenme yaklaşımlarının (dijital ve yüz yüze) daha fazla kullanılması, öğretmenler ve okulların toplumdaki önemli rollerinin fark edilmesi ve daha fazla sayg1 takdir ve destek imkânı bulması, kaliteli öğretim ve öğrenme materyallerinin daha yaygın kullanılması ve öğretmenler arasında işbirliğinin artması gösterilebilir (Winthrop, 2020).

Eğitimde yaşanan sorunların yanı sıra Covid-19 pandemi dönemi, eğitimin yeniden gözden geçirilmesi, temel felsefesinden uzaklaşmış ve birçok açıdan geçerliliği tartışılan yöntemlerin güncellenmesi için bir fırsat olarak görülebilir. Bu yöntemlerin belirlenebilmesi için farklı bakış açılarıyla hazırlanmış raporların incelenmesi bir çözüm sürecini başlatabilir. Bunun yanı sıra bu salgın, tüm dünyanın dikkatini sağlığın yanı sıra eğitim sistemlerinin üzerine çektiği bir dönemde eğitim politikalarını daha kapsayıcı ve adil bir yapıya dönüștürme firsatı sağlamış olabilir. Salgın döneminde en çok dikkat çeken konular arasında sağlik, eğitim ve istihdam gösterilmektedir (Buheji \& Ahmed, 2020). Eğitim açısından hem politika koyucular hem de eğitim liderleri tarafindan bu dönemin bir firsat olarak değerlendirilmesi gerektiği söylenebilir.

Dünya genelinde elde edilen deneyimleri ve önerilen firsatları belirlemek için uluslararası raporların incelenmesi daha kapsamlı bir fikir oluşturması açısında önemlidir. Bu kapsamda incelenen uluslararası raporlarda pandemi döneminde eğitimde yaşanan sorunlar ve bu sorunların getirdiği fırsatların ortaya çıkarılması pandemi sonrası eğitim sürecini daha iyi anlamaya katkı sağlayabilir. Bu noktada bu çalışmanın amacı pandemi dönemini eğitim açısından inceleyerek, ortaya çıkan sorunları ve bu sürecin yaratığı firsatları belirlemektir. Bu amaç doğrultusunda aşağıdaki sorulara yanıt aranmıştır.

1. Pandemi sürecinde eğitimde yaşanan sorunlar nelerdir?

2. Pandemi sürecinde eğitimde yaşanan sorunların yarattığı eğitim firsatları nelerdir?

\section{Yöntem}

$\mathrm{Bu}$ çalışmada pandemi dönemi eğitim açısından ele alınarak sorunlar ve fursatlar incelenmiştir. Çalışmada nitel araştırma yöntemlerinden temel araştırma kullanılmıştır. Temel araştırma bilgi için bilgi üreten, bir olguyu araştırırken o olguyla ilgili gerçekliğe ulaşmayı hedefleyen araştırmadır (Patton, 2014). Bu araştırmada da pandemi sürecinde eğitim bir olgu olarak ele alınmış ve bu süreç içinde yaşanan zorluklar ve firsatlar ortaya çıkarılmıştır.

\section{Verilerin toplanması ve Analizi}

Araştırmada doküman analizi kullanılmıştır. Doküman analizi yazılı belgelerin içeriğini analiz eden (Wach, 2013), araştırılması istenen olgu veya olgular hakkında bilgi içeren materyallerin analizin içeren bir veri analiz tekniğidir (Yıldırım ve Şimşek, 2013). Doküman analizi araştırmacının konuyu daha iyi anlamasına, konuya ilişkin belirsizlikleri gidererek bilgiyi keşfetmesine yardımcı olur (Merriam, 2009). Doküman analizi dokümanlara ulaşma, orijinalliğini kontrol etme, dokümanları anlama, veriyi analiz etme ve veriyi kullanma olmak üzere beş aşamadan oluşmaktadır (Yıldırım ve Şimşek, 2013). Araştırmanın dokümanlara ulaşma aşamasında Covid 19 sürecinde eğitime ilişkin yazılan raporlar örnekleme alınmıştır. Orijinalliğin kontrolünde ulaşılan belgelerin web sayfaları kontrol edilerek belgeler teyit edilmiştir. Araştırma kapsamında Ekonomik Kalkınma ve İşbirliği Örgütü (OECD, 2020b), Birleşmiş Milletler Eğitim, Bilim ve Kültür Örgütü (UNESCO, 2020) ve Dünya Bankası (2020) tarafindan yayınlanan eğitim raporları incelenmiş̧tir. Dokümanları anlama aşamasında ulaşılan belgelerin araştırmanın amacına uygunlukları kontrol edilmiştir. Veri analizinde önce örnekleme karar verilmiştir. Örnekleme alınan raporlar Covid19 sürecinde eğitimde 
ortaya çıkan sorunlar ve firsatlar açısından incelenmiştir. Araştırmada ortaya çıkan raporlar sorunların ve firsatların her biri bir alt tema olarak ele alınmış ve benzer sorunlar ve firsatlar birleştirilerek ana temalar oluşturulmuştur. Araştırma kapsamında Ekonomik Kalkınma ve İşbirliği Örgütü (OECD, 2020b), Birleşmiş Milletler Eğitim, Bilim ve Kültür Örgütü (UNESCO, 2020a) ve Dünya Bankası (2020) tarafından yayınlanan ve incelenen raporlar aşağıda Tablo 1'de verilmiştir.

Tablo 1: Araştırma Kapsamında İncelenen Raporlar

\begin{tabular}{lll}
\hline \multicolumn{1}{c}{$\begin{array}{c}\text { Rapor Adı } \\
\text { A framework to guide an education response } \\
\text { to the COVID-19 Pandemic of 2020 }\end{array}$} & $\begin{array}{c}\text { Reimers ve Schleicher (2020) } \\
\text { OECD }\end{array}$ \\
$\begin{array}{l}\text { UNESCO's support: Educational response to } \\
\text { COVID-19 }\end{array}$ & UNESCO & UNESCO \\
$\begin{array}{l}\text { The COVID-19 Pandemıc: Shocks to Education } \\
\text { and Policy Responses }\end{array}$ & Dünya Bankası & Dünya Bankası \\
\hline
\end{tabular}

\section{Geçerlik ve Güvenilirlik}

Nitel Araştırmalarda inandırıcılık, güvenilebilirlik, onaylanabilirlik ve aktarabilirlik kriterleri esas alınmakta ve geçerlik güvenirlik yerine güvenduyulabilirlik kullanılmaktadır (Guba ve Lincoln, 2005; Shenton, 2004). Bu kriterlerden bir ya da daha fazlasının belirtilmesi gerekmektedir (Creswell, 2003). Bu çalışmada da inandırıcılık ve aktarılabilirlik dikkate alınmıştır. İnandırıcılık araştırmanın iç geçerliliği ile ilgilidir ve bulguların gerçeklikle uyumlu olmasıyla ilgilidir (Meriam ve Tisdell, 2005). Araştırmanın inandırıcılığı için uyuşum yüzdesi hesaplanmıştır. Uyuşum yüzdesi hesaplamasında Miles ve Huberman'ın (1994) formülü kullanılmış ve sorunlar için \% 90.75, firsatlar için \% 89.50 bulunmuştur. Araştırmada dış geçerlilik için aktarılabilirlik kullanılmıştır (Guba ve Lincoln, 2005). Bunun için araştırmada kullanılan yöntem, verilerin nasıl kodlandığı ayrıntılı olarak belirtilmiştir.

\section{Bulgular}

Pandemi Covid 19 sürecinde eğitimde ortaya çıkan sorunlar raporlar doğrultusunda incelenmiş ve aşağıda Tablo 2'de verilmiştir. 
Tablo 2: Covid 19 sürecinde eğitimde ortaya çıkan sorunlar

\begin{tabular}{|c|c|c|c|c|}
\hline Sorunlar - Alt Temalar & Unesco & OECD & $\begin{array}{l}\text { Dünya } \\
\text { Bankası }\end{array}$ & Temalar \\
\hline Öğrenmenin kesintiye uğraması & $\mathrm{X}$ & $\mathrm{X}$ & $\mathrm{X}$ & $\begin{array}{l}\text { Öğrenme -Öğretme } \\
\text { Süreciyle İlgili Sorunlar }\end{array}$ \\
\hline Yetersiz beslenme & $\mathrm{X}$ & $\mathrm{X}$ & $\mathrm{X}$ & Sağlık Sorunları \\
\hline Öğretmenler için karışıklık ve stres & $\mathrm{X}$ & & & $\begin{array}{l}\text { Paydaşlardan kaynaklanan } \\
\text { sorunlar }\end{array}$ \\
\hline $\begin{array}{l}\text { Uzaktan eğitim ve hazırlıksız } \\
\text { yakalanan ebeveynler ve öğretmenler }\end{array}$ & $\mathrm{X}$ & $\mathrm{X}$ & & $\begin{array}{l}\text { Paydaşlardan kaynaklanan } \\
\text { sorunlar }\end{array}$ \\
\hline $\begin{array}{l}\text { Uzaktan öğrenmeyi oluşturma, } \\
\text { sürdürme ve geliştirmede zorluklar }\end{array}$ & $\mathrm{X}$ & $\mathrm{X}$ & & $\begin{array}{l}\text { Öğrenme -Öğretme } \\
\text { Süreciyle İlgili Sorunlar }\end{array}$ \\
\hline Çocuk bakımında boşluklar & $\mathrm{X}$ & & & Diğer \\
\hline Yüksek ekonomik maliyetler & $\mathrm{X}$ & & $\mathrm{X}$ & Diğer \\
\hline $\begin{array}{l}\text { Açık kalan okullar ve okul sistemleri } \\
\text { üzerinde artan baskı }\end{array}$ & $\mathrm{X}$ & & & Diğer \\
\hline Okul bırakma oranlarındaki artış & $\mathrm{X}$ & & $\mathrm{X}$ & $\begin{array}{l}\text { Öğrenme -Ö̈ğretme } \\
\text { Süreciyle İlgili Sorunlar }\end{array}$ \\
\hline $\begin{array}{l}\text { Öğretmen, öğrenci velilerin } \\
\text { kendilerini kötü hissetmeleri }\end{array}$ & $\mathrm{X}$ & $\mathrm{X}$ & $\mathrm{X}$ & Sağlık Sorunları \\
\hline $\begin{array}{l}\text { Şiddete ve sömürüye daha fazla maruz } \\
\text { kalma }\end{array}$ & $\mathrm{X}$ & & & Sağlık Sorunları \\
\hline Sosyal izolasyon & $\mathrm{X}$ & & $\mathrm{X}$ & Sağlık Sorunları \\
\hline Öğrenmeyi ölçmede zorluklar & $\mathrm{X}$ & $\mathrm{X}$ & & $\begin{array}{l}\text { Öğrenme -Öğretme } \\
\text { Süreciyle İlgili Sorunlar }\end{array}$ \\
\hline Velilerle iletişim kuramama & & $\mathrm{X}$ & & $\begin{array}{l}\text { Paydaşlardan kaynaklanan } \\
\text { sorunlar }\end{array}$ \\
\hline Teknolojik yetersizlikler & & $\mathrm{X}$ & & Teknolojik sorunlar \\
\hline Müfredat yetersizlikleri & & $\mathrm{X}$ & & $\begin{array}{l}\text { Oğrenme -Oğretme } \\
\text { Süreciyle İlgili Sorunlar }\end{array}$ \\
\hline Teknolojiye ulaşamama & & $\mathrm{X}$ & & Teknolojik sorunlar \\
\hline $\begin{array}{l}\text { Öğretmenlerin teknolojik } \\
\text { yetersizlikleri }\end{array}$ & & $\mathrm{X}$ & & Teknolojik sorunlar \\
\hline Eğitime ulaşmada eşitsizlik & & & $\mathrm{X}$ & $\begin{array}{l}\text { Öğrenme -Öğretme } \\
\text { Süreciyle İlgili Sorunlar }\end{array}$ \\
\hline Öğrencilerin öğrenme kayıpları & & $\mathrm{X}$ & $X$ & $\begin{array}{l}\text { Öğrenme -Öğretme } \\
\text { Süreciyle İlgili Sorunlar }\end{array}$ \\
\hline
\end{tabular}

Tablo 2'de görüldüğü gibi tüm raporlarda ortaya çıkan ortak sorunlar öğrenmenin kesintiye uğraması, yetersiz beslenme, öğretmen, öğrenci ve velilerin kendilerini kötü hissetmeleri olarak belirlenmiştir. Raporlarda ikincil olarak ortaya çıkan sorunlar uzaktan eğitim ve hazırlıksız yakalanan ebeveynler ve öğretmenler, uzaktan öğrenmeyi oluşturma, sürdürme ve geliştirmede zorluklar, öğretmen ve öğrencilerin kendilerini kötü hissetmeleri, yüksek ekonomik maliyetler, okul bırakma oranlarındaki artış, öğrenmeyi ölçmede zorluklar, sosyal izolasyon ve öğrencilerin öğrenme kayıpları olarak ortaya çıkmıştır. Sadece bir raporda ortaya çıkan sorunlar ise çocuk bakımında boşluklar, yüksek ekonomik maliyetler, öğretmenler için karışıklık ve stres, açık kalan okullar ve okul sistemleri üzerinde artan baskı, şiddete ve sömürüye daha fazla maruz kalma, velilerle iletişim kuramama, teknolojik yetersizlikler, müfredat yetersizlikleri, teknolojiye ulaşamama, öğretmenlerin teknolojik yetersizlikleri ve eğitimde ulaşmada eşitsizlik olarak belirlenmiştir. Araştırmada incelenen raporlarda sorunlara ilişkin ortaya çıkan temalar aşağıda Şekil 1'de verilmiştir. 


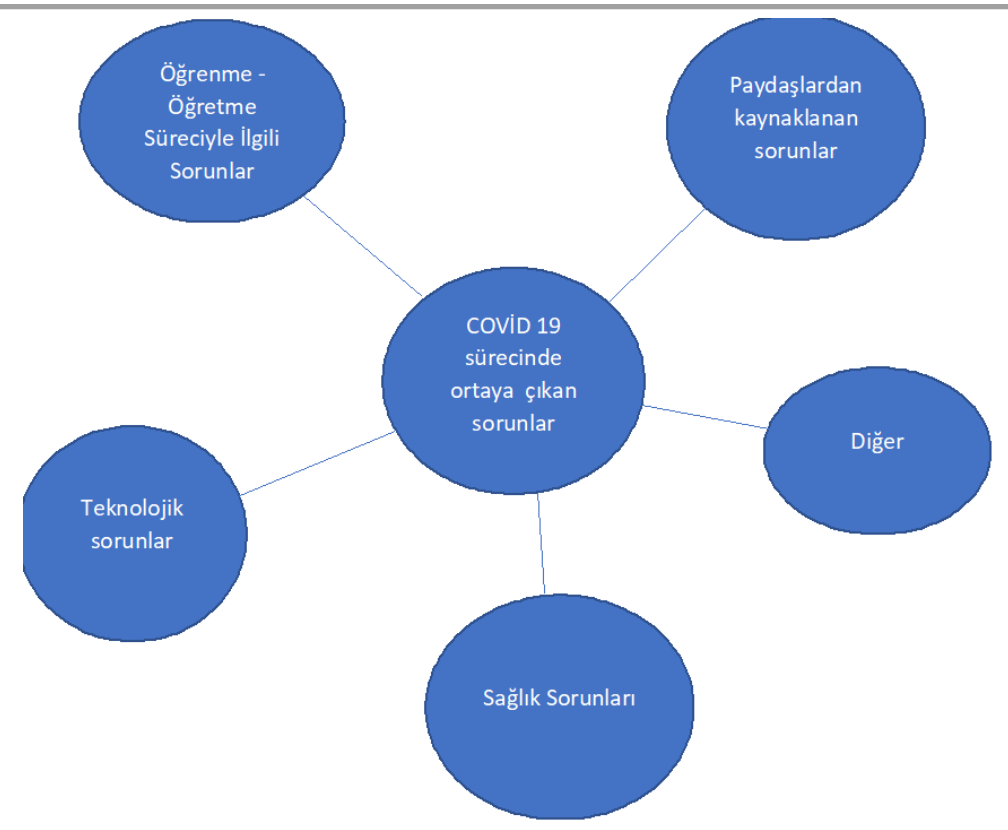

Şekil 1: Covid 19 sürecinde eğitimde ortaya çıkan sorunlara ilişkin temalar

Şekil 1'de görüldüğü gibi raporlarda ortaya çıkan sorunlara ilişkin temalar öğrenme -öğretme süreciyle ilgili sorunlar, paydaşlardan kaynaklanan sorunlar, teknolojik sorunlar, sağlık sorunları ve diğer başlıkları altında toplanmıştır. Temalar altında yer alan sorunlar Şekil 2'de verilmiştir.
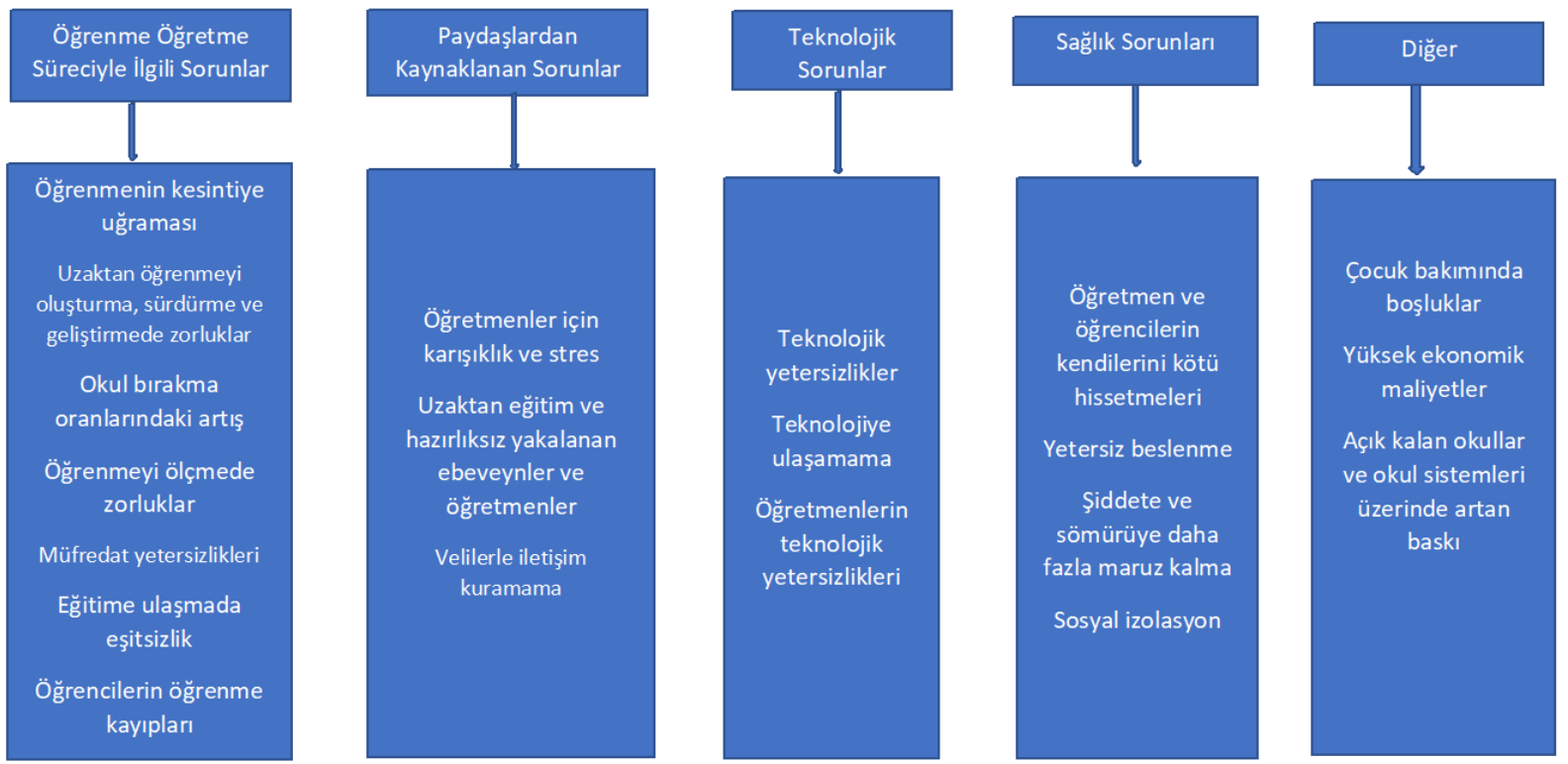

Şekil 2: Temalar Altında Yer Alan Sorunlar

Şekil 2'de görüldüğü gibi öğrenme öğretme süreciyle ilgili sorunlar teması altında yer alan sorunlar öğrenmenin kesintiye uğraması, uzaktan öğrenmeyi oluşturma, sürdürme ve geliştirmede zorluklar, okul bırakma oranlarındaki artıș, öğrenmeyi ölçmede zorluklar, müfredat yetersizlikleri, eğitimde ulaşmada eşitsizlik ve öğrencilerin öğrenme kayıplarıdır. Paydaşlardan kaynaklanan sorunlar teması altında öğretmenler için karışıklık ve stres, uzaktan eğitim ve hazırlıksız yakalanan ebeveynler ve öğretmenler ve velilerle iletişim kuramama yer almıştır. Teknolojik sorunlar teması altında teknolojik yetersizlikler, teknolojiye ulaşamama ve öğretmenlerin teknolojik yetersizlikleri 
yer almıştır. Sağlık sorunları teması altında öğretmen, öğrenci velilerin kendilerini kötü hissetmeleri, yetersiz beslenme, şiddete ve sömürüye daha fazla maruz kalma ve sosyal izolasyon yer almışıtır. Son olarak diğer teması altında çocuk bakımında boşluklar, yüksek ekonomik maliyetler, açık kalan okullar ve okul sistemleri üzerinde artan baskı yer almıştır.

Pandemi Covid 19 sürecinde eğitimde ortaya çıkan sorunların yarattı̆̆ eğitim firsatları incelenmiş ve aşağıda Tablo 3’te verilmiştir.

Tablo 3: Covid 19 sürecinde eğitimde ortaya çıkan sorunların yarattı̆̆ı eğitim firsatları

\begin{tabular}{|c|c|c|c|c|}
\hline Firsatlar - Alt Temalar & Unesco & OECD & $\begin{array}{l}\text { Dünya } \\
\text { Bankası }\end{array}$ & Temalar \\
\hline Yeni iletişim yolları geliştirmek & $\mathrm{X}$ & $X$ & & $\begin{array}{l}\text { Okul Yönetimi } \\
\text { becerileri }\end{array}$ \\
\hline Eğitim planlarını gözden geçirmek & $\mathrm{X}$ & $X$ & $\mathrm{X}$ & $\begin{array}{l}\text { Okul Yönetimi } \\
\text { becerileri }\end{array}$ \\
\hline $\begin{array}{l}\text { Öğretmenlerin mesleki gelişimine önem } \\
\text { vermek }\end{array}$ & $\mathrm{X}$ & $X$ & & $\begin{array}{l}21 \text { yy öğrenme öğretme } \\
\text { becerileri }\end{array}$ \\
\hline Gelecekteki okulları yeniden düşünmek & $\mathrm{X}$ & & & Okulların işlevi \\
\hline $\begin{array}{l}\text { Yeni değerlendirme sistemleri } \\
\text { geliștirmek }\end{array}$ & $\mathrm{X}$ & $\mathrm{X}$ & $\mathrm{X}$ & Yeni eğitim algis1 \\
\hline Okulların işlevini gözden geçirmek & $X$ & & & Okulların İşlevi \\
\hline $\begin{array}{l}\text { Okulları kriz dönemine hazırlıkla hale } \\
\text { getirmek }\end{array}$ & & $\mathrm{X}$ & $\mathrm{X}$ & $\begin{array}{l}\text { Alternatif eğitim } \\
\text { yapılanmaları }\end{array}$ \\
\hline Uzaktan eğitim programları geliştirmek & $\mathrm{X}$ & $\mathrm{X}$ & $\mathrm{X}$ & $\begin{array}{l}\text { Alternatif eğitim } \\
\text { yapılanmaları }\end{array}$ \\
\hline $\begin{array}{l}\text { Öğretmenlerin teknoloji becerilerinin } \\
\text { artması }\end{array}$ & $X$ & $X$ & & $\begin{array}{l}21 \text { yy ögrenme öğretme } \\
\text { becerileri }\end{array}$ \\
\hline $\begin{array}{l}\text { Öğrencilerin teknoloji becerilerinin } \\
\text { artması }\end{array}$ & & $\mathrm{X}$ & $\mathrm{X}$ & $\begin{array}{l}21 \text { yy öğrenme öğretme } \\
\text { becerileri }\end{array}$ \\
\hline Ebeveyn katılımını artırmak & $\mathrm{X}$ & $\mathrm{X}$ & & Veli katılımı \\
\hline Ebeveynlere yetkinlik kazandırma & & $X$ & & Veli katılımı \\
\hline $\begin{array}{l}\text { Bu süreçte işsiz kalanlara yeni beceriler } \\
\text { kazandırmak için çevrimiçi öğrenme } \\
\text { yollarını genişletmek }\end{array}$ & & $X$ & $\mathrm{X}$ & $\begin{array}{l}21 \text { yy öğrenme öğretme } \\
\text { becerileri }\end{array}$ \\
\hline $\begin{array}{l}\text { Öğretmenlerin dijital cihazları eğitime } \\
\text { entegre etmek için gerekli teknik ve } \\
\text { pedagojik becerilerinin geliştirilmesi }\end{array}$ & $\mathrm{X}$ & $\mathrm{X}$ & & $\begin{array}{l}21 \text { yy öğrenme öğretme } \\
\text { becerileri }\end{array}$ \\
\hline $\begin{array}{l}\text { Yeni çevrimiçi öğrenme platformlarının } \\
\text { oluşturulması }\end{array}$ & $X$ & $X$ & $\mathrm{X}$ & $\begin{array}{l}\text { Alternatif eğitim } \\
\text { yapılanmaları }\end{array}$ \\
\hline $\begin{array}{l}\text { Salgından sonra ebeveynler, } \\
\text { öğretmenler, kitle iletişim araçları, } \\
\text { eğitim politikacıları ve diğerleri eğitim } \\
\text { sürecindeki rollerinin yeniden } \\
\text { belirlenmesi }\end{array}$ & $\mathrm{X}$ & & $\mathrm{X}$ & Yeni Eğitim algisı \\
\hline $\begin{array}{l}\text { Daha sağlıklı okul koşullarının } \\
\text { sağlanması }\end{array}$ & $X$ & $X$ & $\mathrm{X}$ & Okulların İşlevi \\
\hline $\begin{array}{l}\text { Eğitim sistemlerinin daha güçlü ve adil } \\
\text { hale getirilmeye çalışılması }\end{array}$ & $\mathrm{X}$ & & $\mathrm{X}$ & Yeni Ĕ̈itim algısı \\
\hline $\begin{array}{l}\text { Okullarda öğrenci sağlık takip } \\
\text { sistemlerinin kurulması }\end{array}$ & & & $\mathrm{X}$ & $\begin{array}{l}\text { Okul Yönetimi } \\
\text { becerileri }\end{array}$ \\
\hline Okul Aile bağının güçlendirilmesi & $\mathrm{X}$ & & & Veli katılımı \\
\hline $\begin{array}{l}\text { Müfredat oluşturma aşamasına velilerin } \\
\text { dâhil edilmesi }\end{array}$ & $\mathrm{X}$ & & & Veli katılımı \\
\hline $\begin{array}{l}\text { Öğretmen ve öğrenci sağllı̆ı̆ını ön plana } \\
\text { çıkaran politikalar oluşturmak }\end{array}$ & $\mathrm{X}$ & & & $\begin{array}{l}\text { Okul Yönetimi } \\
\text { becerileri }\end{array}$ \\
\hline
\end{tabular}


Tablo 3'te görüldüğü gibi tüm raporlarda ortaya çıkan eğitime ilişkin firsatlar eğitim planlarını gözden geçirmek, yeni değerlendirme sistemleri geliştirmek, uzaktan eğitim programları geliştirmek, yeni çevrimiçi öğrenme platformlarının oluşturulması, daha sağlıklı okul koşullarının sağlanmasıdır. Raporlarda ortaya çıkan ikincil eğitim firsatları yeni iletişim yolları geliştirmek, öğretmenlerin mesleki gelişimine önem vermek, okulları kriz dönemine hazırlıkla hale getirmek, öğretmenlerin teknoloji becerilerinin artması, öğrencilerin teknoloji becerilerinin artması, ebeveyn katılımını artırmak, bu süreçte işsiz kalanlara yeni beceriler kazandırmak için çevrimiçi öğrenme yollarını genişletmek, öğretmenlerin dijital cihazları eğitime entegre etmek için gerekli teknik ve pedagojik becerilerinin geliştirilmesi, salgından sonra ebeveynler, öğretmenler, kitle iletişim araçları, eğitim politikacıları ve diğerleri eğitim sürecindeki rollerinin yeniden belirlenmesi ve eğitim sistemlerinin daha güçlü ve adil hale getirilmeye çalışılmasıdır. Sadece bir raporda ortaya çıkan eğitim fırsatları ise ebeveynlere yetkinlik kazandırma, okul aile bağının güçlendirilmesi, müfredat oluşturma aşamasına velilerin dahil edilmesi ve öğretmen ve öğrenci sağlığını ön plana çıkaran politikalar oluşturmaktır. Araştırmada incelenen raporlarda eğitim firsatlarına ilişkin ortaya çıkan temalar aşağıda Şekil 3 'te verilmiştir.

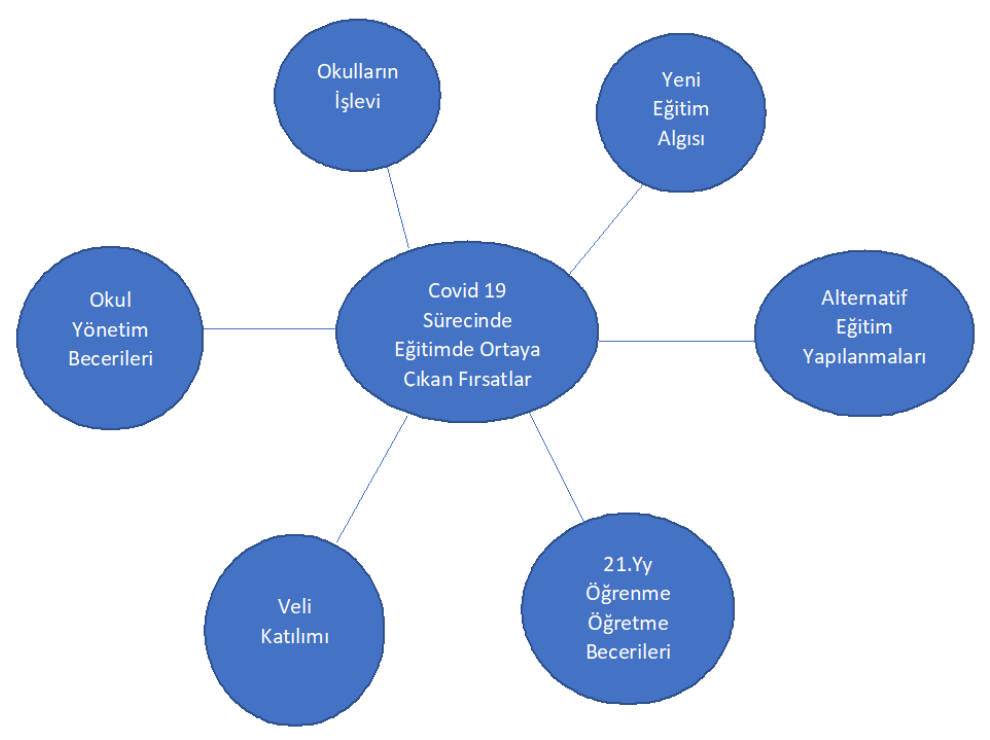

Şekil 3: Covid 19 sürecinde eğitimde ortaya çıkan firsatlara ilişkin temalar

Şekil 3’te görüldüğü gibi raporlarda ortaya çıkan firsatlara ilişkin temalar okulların işlevi, yeni eğitim algısı, alternatif eğitim yapılanmaları, 21.yy öğrenme öğretme becerileri, veli katılımı ve okul yönetim becerileri başlıkları altında toplanmıştır. Temalar altında yer alan firsatlar Şekil 4 'te verilmiştir. 

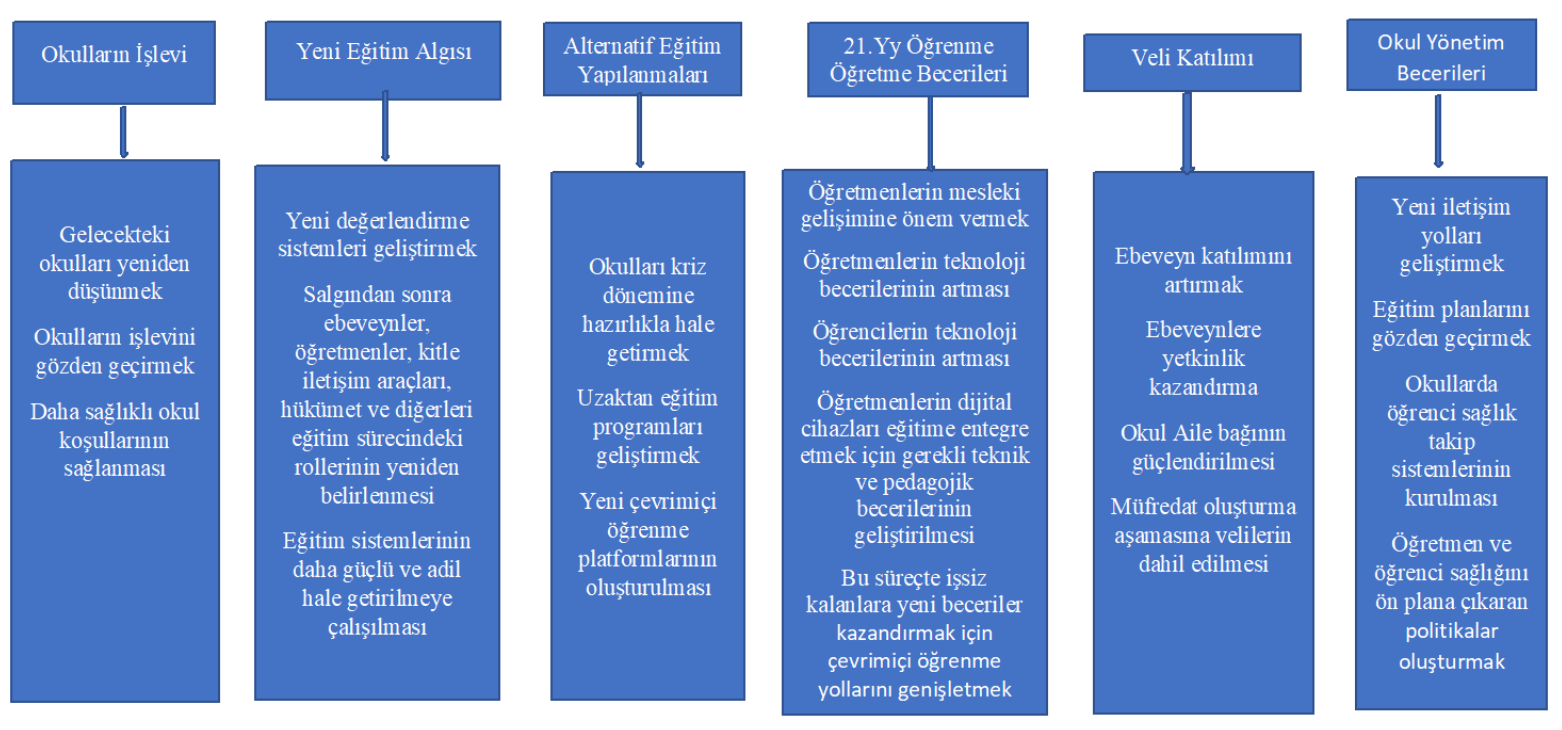

Şekil 4: Temalar Altında Yer Alan Fırsatlar

Şekil 4'te görüldüğü gibi okulların işlevi teması altında gelecekteki okulları yeniden düşünmek, okulların işlevini gözden geçirmek ve daha sağlıklı okul koşullarının sağlanması yer almıştır. Yeni eğitim algısı teması altında yeni değerlendirme sistemleri geliştirmek, salgından sonra ebeveynler, öğretmenler, kitle iletişim araçları, eğitim politikacıları ve diğerleri eğitim sürecindeki rollerinin yeniden belirlenmesi ve eğitim sistemlerinin daha güçlü ve adil hale getirilmeye çalışılması yer almıştır. Alternatif eğitim yapılanmaları teması altında okulları kriz dönemine hazırlıkla hale getirmek, uzaktan eğitim programları geliştirmek ve yeni çevrimiçi öğrenme platformlarının oluşturulması yer almıştır. 21.yy öğrenme öğretme becerileri teması altında öğretmenlerin mesleki gelişimine önem vermek, öğretmenlerin teknoloji becerilerinin artması, öğrencilerin teknoloji becerilerinin artması, öğretmenlerin dijital cihazları eğitime entegre etmek için gerekli teknik ve pedagojik becerilerinin geliştirilmesi ve bu süreçte işsiz kalanlara yeni beceriler kazandırmak için çevrimiçi öğrenme yollarını genişletmek yer almıştır. Veli katılımı teması altında ebeveyn katılımını artırmak, ebeveynlere yetkinlik kazandırma, okul Aile bağının güçlendirilmesi ve müfredat oluşturma aşamasına velilerin dahil edilmesi yer almıştır. Son olarak okul yönetim becerileri altında yeni iletişim yolları geliştirmek, eğitim planlarını gözden geçirmek, okullarda öğrenci sağlık takip sistemlerinin kurulması ve öğretmen ve öğrenci sağlığını ön plana çıkaran politikalar oluşturmak yer almıştır.

\section{Tartışma Sonuç ve Öneriler}

Bu çalışmada Covid19 pandemi dönemi eğitim açısından incelenerek, ortaya çıkan sorunlar ve bu sürecin yaratığı firsatlar incelenmiştir. Bu doğrultuda Ekonomik Kalkınma ve İşbirliği Örgütü (OECD, 2020b), Birleşmiş Milletler Eğitim, Bilim ve Kültür Örgütü (UNESCO, 2020a) ve Dünya Bankası (2020) tarafından yayınlanan eğitim raporları incelenmiştir.

İnsanlık tarihi geçmişten günümüze birçok felaket atlatmış ve bu felaketlerden ders çıkarmış, felaketlere karşı önlemler geliştirerek ve bu önlemleri yaygınlaştırarak varlığını devam ettirebilmiştir. Örneğin, firtınalar, yangınlar, depremler ve salgın hastalıklar dünyada insan yaşamını tehlikeye atmış veya yaşam şeklini değiştirmeye zorlamıştır. Küresel düzeyde bir salgın geçtiğimiz yüzyılda insanlar için yıkıcı bir risk olduğunu sürekli hissettirse de, COVID-19 dünya çapında toplumları, sağlık sistemlerini, ekonomileri ve yöneticileri hazırlıksız yakalamış ve sistemleri alt üst etmiştir. Eğitim açısından krizdeki firsatlar neler olabilir ve bu durumu daha müreffeh, eşitlikçi ve 
sürdürülebilir bir dünya inşa etmek için nasıl kullanabilirler sorusu çalışmanın temelini oluşturmuştur. Bu temel doğrultusunda araştırmada ortaya çıkan bulgular sorunlar ve firsatlar olarak ele alınarak tartışılmış ve öneriler getirilmiştir.

İncelenen eğitim raporlarında ortaya çıkan sorunlara ilişkin temalar değerlendirildiğinde sorunların bazılarının eğitimciler tarafından ön görülebilir sorunlar olduğu görülürken bazı sorunların dikkat çekici yönleri ortaya çıkmıştır. Genel olarak öğrenme-öğretme süreciyle ilgili sorunlar, paydaşlardan kaynaklanan sorunlar, teknolojik sorunlar öngörülebilir sorunlar olarak değerlendirilebilir. Bu temalar literatürde yer alan diğer çalışmalarla (Buheji \& Ahmed, 2020; PHA, 2020; Saavedra, 2020) benzerlik göstermektedir. Alanyazın incelendiğinde de Covid 19 sürecinde eğitimde öğrenme kaybının olduğu, okulu bırakma oranın arttığı, beslenme sorunlarının ortaya çıktığ 1 (Saavedra, 2020), eğitime erişimde eşitsizlik olduğu (Saran, 2020) görülmektedir. Öğrenme ve öğretme süreciyle ilgili sorunlar teması altında ele alınan uzaktan eğitim sürecine uyum sağlamakta yaşanan sorunlar, müfredat yetersizliği ve öğrenmeyi ölçmede yaşanan sorunlar yakın zamanda eğitimin bir sistem olarak kendini güncellememesi ve alışılagelmiş yöntemlerin yeterli olduğu algısının bir sonucu olarak değerlendirilebilir. Ailelerin, eğitimi sürecini sadece okul ile eşdeğer görmeleri ve öncelikle kendi bireysel gelişimleri ve çocuklarının öğrenme süreçleri ve beceri gelişimleri konusunda yeterince bilgi sahibi olmamaları bu çalışmada paydaşlardan kaynaklanan sorunlar temasının ana gerekçelerinden birisi olarak değerlendirilebilir. Ailelerin çocukların teknoloji ilişkilerine yönelik algılarının sadece sosyal medya veya dijital oyunlar ile sınırlı olması, teknolojik araçlarının bir eğitim aracı olarak görülmemesine sebep olmuştur. Ailelerin bu gerekçeyle çocuklarını koruma adına evlerine yeterli teknolojik alt yapı (sınırsız internet bağlantısı, PC, dizüstü bilgisayarı, tablet veya akıllı telefon gibi) sağlamamış olmaları bu süreçte ortaya çıkan teknolojik sorunların gerekçelerinden birisi olarak görülebilir. Bununla birlikte sorunlarda ortaya çıkan bir başka önemli konu öğretmenlerin teknolojik yetersizlikleridir. Bu durum sadece eğitim raporlarında yere almamakta bu süreçte yapılan çalışmalarda da ortaya çıkmaktadır. Huber ve Helm (2020) tarafından yapılan çalışmada da öğretmenlerin dijital yeterliklerinin orta düzeyde olduğu ve İsviçreli ve Avusturyalı öğretmenlerin Alman öğretmenlere göre daha iyi performans sergilediği ortaya çıkmıştır. Bu noktada okullar aynı zamanda öğretmenlerin dijital yeterliklerini geliştirmek için mesleki gelişim ve uygulama stratejileri geliştirebilirler (Huber ve Helm, 2020).

Diğer taraftan sağlı sorunları teması altında toplanan sorunların bazıları araştırma kapsamında dikkat çeken ve öncelikli sorunlar olarak ele alınması gereken sorunlar olarak görülmüştür. Öğrenci ve öğretmenlerin yaşam standartlarının ve alışkanlıklarının sosyal izolasyon gerekçesiyle sınırlanmış olması kendilerini kötü hissetmelerine sebep olmuş olabilir ve bu sorun öngörülebilirken, bir çocuğun evde ailesi ile birlikte olmasının onun beslenme yetersizliği yaşaması veya şiddete ve sömürüye daha çok maruz kalması gibi bir sonucun ortaya çıkması dikkat çekici bir sonuç olarak değerlendirilmelidir. Eğitim raporlarından elde edilen bu sonuçlar Koh ve ark. (2020) tarafından yapılan araştırmanın sonuçlarıyla benzerlik göstermektedir. Sağlık teması altında değerlendirilen fiziksek sağlı̆ın korunması Covid-19 salgınının doğrudan bir sonucu olarak ele alınabilir ve çocukların bağışıklık sistemleri, alerjik duyarlılıkları ve genetik sorunlarından kaynaklanabilir, ancak özel eğitim ihtiyacı olan öğrencilerin eğitim sorunlarının raporlarda yer almaması bir diğer dikkat çeken konudur.

Sağlık sorunları teması altında salgın döneminde öğrenci ve öğretmenlerin psikolojik iyi oluşlarıyla ilgili sorunlara raporların tamamında vurgulanmıştır. Aile bireylerinin tüm zamanlarını birlikte geçirmek zorunda olmaları kişisel alanlarının kısıtlanması ve kendilerine zaman ayıramamaları psikolojik iyi oluşlarını olumsuz etkilerken, bu durumun bir sorun olarak ortaya çıkmasının görünmeyen sebeplerinden birisi öğrencilerin kendi kendilerine öğrenme becerilerinin yetersiz olması olabilir. Bu sonuç Yusuf, (2011)'in çalışmasında elde ettiği sonuçlarla benzerlik göstermektedir. Hargreaves'de (2020) uzun süre evde kalan öğrencilerin yüz yüze öğretmen 
desteğini kaybettiğini, birçoğunun ailesinin herhangi birinin hastalandığını gördüğünü ve bu yüzden kendilerini kötü hissettiklerini belirtmiştir.

Diğer teması altında ortaya çıkan sorunların çocuk bakımında boşluklar, yüksek ekonomik maliyetler, açık kalan okullar ve okul sistemleri üzerinde artan bask1 olduğu görülmektedir. Hargreaves'de (2020) bu süreçte ailelerin tüm gün evde çocuklarıyla birlikte olmak zorunda kalmaları nedeniyle çocuk bakımına zorlandıklarını belirtmiş̧ir.

Yapılan inceleme sonucunda Covid-19 salgını döneminde yaşanan sorunların liderlere, politika oluşturuculara ve eğitimcilere işaret ettiği bazı firsatların olduğu da görülmektedir. Yaşanan sorunların tekrar etmemesinin önüne geçmek adına alınacak önlemler ve yapılacak düzenlemeler daha adil, daha kapsayıcı ve sürdürülebilir bir eğitim sistemi sağlamak için önemli bir firsat olarak değerlendirilebilir. Çalışma kapsamında incelenen eğitim raporlarının işaret ettiği firsatlar okulların işlevleri, yeni eğitim algısı, alternatif eğitim yapılanmaları, 21. Yy öğrenme öğretme becerileri, okul yönetimi becerileri temaları altında toplanmıştır. Raporlarda belirtilen firsatlardan birisi Covid-19 sonras1 eğitim faaliyetlerinin yeni eğitim algısından başlayarak eğitimin tüm boyutlarında değişim yaşanacağının yordayıcısı olduğu şeklinde yorumlanabilir. Bu sorunlar, eğitim sisteminde yıllar içinde oluşan tek dizelik ve sıradanlıktan uzaklaşmak ve eğitim sitemini yeniden yapılandırmak için bir firsat sağlamıştır.

Okulların işlevleri temasının altında yer alan alt temalar salgın sonrası okulların işlevlerinin sinıf yapısından fiziki veya psikolojik sağlığın göz önünde bulundurularak yeniden düzenlenmesinin gerekliliğini ön plana çıkarmıştır. Daniel (2020)'de Covid19 pandemi sürecinden sonra okullar, öğretmenler ve öğrencilerin, COVID-19'un öğrenme kayıplarının neden olduğu hasarı onarmak için esnek yollar aramaya devam edeceğini belirtmektedir. Normalde sınıflarda veya kampüslerde yüz yüze eğitim veren kurumlar büyük olasılıkla bir miktar rahatlama ile bu öğretim şekline dönecek olsalar da COVID-19 krizi sırasında yaptıkları özel düzenlemeler kalıcı bir iz birakacaktır. Yükseköğrenimde çevrimiçi öğrenmenin genişlemesi daha da hızlanacak ve okullar, teknolojiye dayalı öğrenmenin en yararlı buldukları yönlerini sürdürmek için kendilerini daha sistematik bir şekilde organize edecektir. Tüm kurumlar eğitim ve öğretim görevlerini kriz zamanında sürdürmek için koydukları mekanizmalardan faydalanacaktır (Daniel, 2020).

Okullar eğitim öğretim sürecinde sadece bilgi edinme misyonunu yerine getirmekle kalmaz aynı zamanda öğrencilerin sosyalleşme ihtiyacını da karışılar. Evde her ne kadar sanal bir öğrenme ortamı oluşsa da öğrenciler arkadaşlarıyla ilgi alanlarını, düşüncelerini, umutlarını ve duygularını paylaşacakları fiziksel bir mekândan mahrum kalmaktadır. Okul, çocukların özgüven, dostluk, empati, katılım, sayg1, minnet, merhamet ve sorumluluk gibi sosyal yeterlikleri öğrenip geliştirebilecekleri yapılandırılmış bir ortam sağlar (Zins, Bloodworth, Weissberg ve Walberg, 2007). Bu noktada Covid19 süreci okulların işlevinin yeniden düşünme firsatı yaratmışıtır. Burada ortaya çıkan önemli bir sonuç okulların daha sağlıkı koşulları karşılamasıdır. Okulların kapatılması ve bu durumun öğrenciler üzerindeki psikolojik etkisi önemli bir konudur. Okulların kapanmasını özellikle sosyoekonomik açıdan dezavantajlı öğrenciler için önemli bir sorundur. Bu öğrenciler eğitim, beslenme ve sağlık ihtiyaçları için okullara güvenmektedir (Colao, Piscitelli, Pulimeno, Colazzo, Miani, Giannini, 2020). Bu noktada okulların artık sağlık konusunda daha önemli bir role sahip olması gerektiği söylenebilir. Nitekim Pakkari ve Okkan (2020) artık öğretmenlerin sağlıklı alışkanlıkları (fiziksel aktivite, iyi kişisel hijyen ve dengeli beslenme) teşvik ederek ve riskli davranışların sonuçları hakkında farkındalığı artırarak öğrenciler için sağlık rehberi olarak hareket etmeleri gerektiğini belirtmiştir. Okullar aynı zamanda öğretmenlerin dijital yeterliklerini geliştirmek için mesleki gelişim ve uygulama stratejileri geliştirebilirler (Huber ve Helm, 2020).

İncelenen eğitim raporlarında özellikle öne çıkan konulardan birisinin politika koyucular, eğitim yöneticileri, öğretmenler, öğrenciler ve veliler açısından eğitimin varlığı, gerekliliği ve işlevine yönelik algının farklılaştığı ve günlük olağan bir aktivitenin çok ötesinde anlamlar 
taşıdığının tekrar anlaşılması olduğu görülmüştür. Bu kapsamda ölçme değerlendirme yöntemlerinin öncelikli olarak yeniden belirlenmesi ve farklı becerileri farklı yöntemler ve araçlar kullanarak ölçme yönünde yapılandırılmasının gerekliliği ifade edilmiştir. Okulların kapanması ve yüz yüze eğitime ara verilmesi kullanımda olan birçok ölçme yöntemini devre dışı bırakmıştır. Bu süreçte öğrenci mağduriyetlerinin yaşanmaması adına eğitimde normal şartlarda kullanılmayan çevrim içi ölçme ve esnek değerlendirme yöntemleri bu sürecin getirdiği tolerans ölçüsünde kabul edilebilir olsa da özellikle akademik başarıların ölçülmesi konusunda adil değerlendirmeden uzak kalmıştır. Bu durum öncelikli olarak eğitimcileri rahatsız ederken, raporlarda vurgulanan bulgulara göre öğrenci ve veliler de bu durumdan rahatsız olmuştur. Bu sorun yeni ölçme ve değerlendirme yöntemlerinin eğitim sistemine uyarlanması ve kullanılması için bir firsat olarak değerlendirilebilir. UNESCO (2020b) tarafından yayınlanan raporda da bu süreçte öğrenme çıktılarını değerlendirmek ve doğrulamak için uygun yöntemler kullanılması gerektiği, uzaktan sunulacak kaynaklar ve dersler arasında, değerlendirmeyi çeşitli düzeylerde entegre etmenin önemli olduğu, değerlendirme süreçlerinin yeniden gözden geçirilmesi gerektiği vurgulanmıştır.

İncelenen eğitim raporlarında yenilikçi bir yaklaşım olarak dikkat çeken bir diğer eğitim fırsatı ise alternatif (hibrit) eğitim yapılanmalarının mümkün olduğunu göstermesidir. Geleneksel eğitim uygulamalarına salgın döneminde ara verilmesi ve uzaktan eğitime geçilmesi uzaktan eğitimin geleneksel eğitim uygulamalarına bir alternatif oluşturduğunun anlaşılmasını sağlamıştır. Planlı ve bilimsel yöntemlerle yapılan uzaktan eğitimin 21. yy eğitim anlayışının yeniden oluşturulması için bir firsat olarak değerlendirilebilir. Salgın sonrası normalleşme döneminde ve devamında okullarda yapılan yüz yüze derslere ek olarak belirlenecek bazı derslerin uzaktan eğitimle yapılması, okulların uzaktan eğitim alt yapılarının güncel kalmasına katkı sağlayacağı gibi ders materyallerinin dijital ortama aktarılması, öğretmen ve öğrencilerin uzaktan eğitim platformlarını kullanma becerilerinin gelişmesi bakımından önemli bir firsat olarak değerlendirilebilir.

Son olarak, eğitim raporlarının öne çıkardığı ve yeni eğitim anlayışına yön verebilecek fırsatlar arsında eğitim sürecine veli katılımının artırılması, velilerin müfredat ve eğitim işleyişi konusunda yetkinlik kazanması evde eğitim sürecine katkı sağlayacaktır. Tüm bu yeniliklerinin yönetilmesi ise salgın sonrasında oluşturulacak yeni okul yönetimi felsefesi ve politikalarıyla mümkün olabilir. Bu çerçevede, eğitim raporlarında vurgulanan firsatların etkili bir uygulamas1 ancak yeni okul yönetimi yaklaşımlarıyla desteklenmelidir. Okulların yönetim kademesinde oluşturulacak kriz yönetim kurulları marifetiyle olası riskleri ön görerek ve bilim insanlarının önerileri doğrultusunda kriz yönetimi yapılabilmesi için bir firsat olabilir. Bu kurullar gelecekte yaşanabilecek olası okul kapanışlarında eğitimin aksamadan devam etmesini sağlayacak eylem planları hazırlayabilirler. Bu değişikliklerin yapılabilir olduğunu ve gerektiğinde toplumun bir bütün olarak hareket edebileceğini, birlikte zorlukların üstesinden gelmenin daha olası olduğunu göstermesi bakımından yaşanan salgın dönemi bir firsat olarak görülebilir. UNESCO (2020c) eğitimde her seviye için hazırlanan beklenmedik durum planlarının, eğitimin sürekliliğinin ve öğrenenlerin, öğretmenlerin ve eğitim altyapısının güvenliğinin sağlanmasına yardımcı olacağını belirtmektedir. Bu planlar devam eden bir kriz sırasında geliştirilebilir, fakat ideal olarak krizler ortaya çımadan önce geliştirilmelidir. Beklenmedik durum planları kriz ortaya çıkmadan önce eğitim kurumlarının krize nasıl her düzeyde tepki vereceği konusunda ayrıntılı rehberlik yapmalıdır.

Sonuç olarak Covid19 pandemi süreci eğitim açısından sorunlar getirmekle birlikte bu sorunlar yeni firsatlar oluşturmuştur. Bu süreçte ortaya çıkan sorunlar öğrenme -öğretme süreciyle ilgili sorunlar, paydaşlardan kaynaklanan sorunlar, teknolojik sorunlar ve sağlık sorunları temaları altında ele alınmıştır. Sorunlar aynı zamanda sürece ilişkin firsatları da oluşturmaktadır. Öğrenme öğretme süreciyle ilgili sorunlar, paydaşlardan kaynaklanan sorunlar ve sağlık sorunları okulların işlevini yeniden düşünmek, ortaya çıkan yeni eğitim algısıyla alternatif eğitim yapılanmalarına firsat oluşturmaktadır. Benzer şekilde teknolojik sorunlar, öğrenme -öğretme süreciyle ilgili sorunlar ve 
paydaşlardan kaynaklanan sorunlar da 21.yy öğrenme öğretme becerileri, veli katılımı ve okul yönetim becerilerini geliştirme açısından firsat oluşturmaktadır.

\section{Öneriler}

Uluslararası iletişim ve etkileşimin insanlık tarihi boyunca en yaygın olarak yaşandığı bir dönemde hayatın tüm yönlerini etkileyen Covid-19 salgını hizmet sektörlerinin birçoğunu değişeme zorlamıştır. $\mathrm{Bu}$ kapsamda eğitimde yaşanan sorunlar ve bu sorunların işaret ettiği firsatlar doğrultusunda eğitim politikası oluşturucular, okul yöneticileri, öğretmenler ve veliler için oluşturulan bazı önerilerden bahsedilebilir.

Öncelikli olarak okul bina planlamalarının gözden geçilmesi ve eğitimde kriz yönetimi ilkelerine uygun okul binalarının yapılması ve kullanımda olan okul binalarının sağlığa uygunluk, sosyal mesafeye uygunluk ve tahliye yönetmenliklerine uygunluk bakımından yeniden düzenlenmesi önerilir. Eğitim sisteminin daha adil, daha kapsayıcı ve sürdürülebilir olmasını sağlayacak yasal düzenlemelerin oluşturulması ve bu düzenlemeler doğrultusunda uygulamaların titizlikle yürütülmesi önerilebilir. Okul aile iletişim merkezleri oluşturularak eğitim uygulamaları ve müfredat konusunda öğretmen veli iletişiminin devamlılığı sağlanarak velilerin daha katılımcı olmaları ve modern eğitimin okulla sınırlı kalmaması sağlanmalıdır. Öğrenci ölçme ve değerlendirme yöntemlerinin çeşitlendirilmesi ve öğrencilerin kendi kendine öğrenme becerileri kazanmaları sağlanmalıdır. Okulların işlevleri tekrar gözden geçirilerek, geleceğin okullarını oluşturma yönünde planlamalar yapılmalı, okulların toplum sağlığı ve mesleki gelişim alanındaki rolleri yeniden şekillendirilmelidir.

Tüm eğitim düzeyleri için okullarda uzaktan eğitim birimleri oluşturulmalı ve bu birimlere uzaktan eğitim için gereken teknik destek sağlayabilecek kadrolar tahsis edilmelidir. Tahsis edilen bu kadrolar mağfireti ile uzaktan eğitim programları geliştirilmeli ve bu programlar çerçevesinde her dönem eğitim kadrosu ve öğrencilere 21. yy öğrenme-öğretme becerileri kazandırmak için teknik destek sağlanarak uzaktan eğitim sistemine uyum sağlamaları desteklenmelidir. Okul yönetiminin kriz dönemlerine hazırlıklı olma becerisi kazanabilmesi adına gerekli yetki ve özerkliğin sağlanması için yasal düzenlemeler yapılmalıdır. Okul yönetimleri öğretmen öğrenci ve velilerle sürdürülebilir iletişim kanalları belirlemeli ve eğitim planlarının eğitim kriz yönetimi kurullarının önerileri doğrultusunda esnek ve uyarlanabilir olarak hazırlanmasını sağlamalıdır.

\section{Kaynakça}

Bowman, K. ve J. Rice Et A. Warner (2014). The ethics of early warning systems for climate change. Dans: Reducing Disaster: Early Warning Systems for Climate Change. SINGH, A. et Z. ZOMMERS (Éditeurs), Springer, Dordrecht, Pays-Bas, pp. 283-304.

Buheji, M., \& Ahmed, D. (2020). Foresight of Coronavirus ( COVID-19) Opportunities for a Better World, (March). https://doi.org/10.5923/j.economics.20201002.05.

Colao, A., Piscitelli, P., Pulimeno, M., Colazzo, S., Miani, A. ve Giannini, S. (2020). Rethinking the role of the school after COVID-19, Lancet Public Health, https://www.thelancet.com/journals/lanpub/article/PIIS2468-2667(20)30124-9/fulltext

Daniel S. J. (2020). Education and the COVID-19 pandemic. Prospects, 1-6. Advance online publication. https://doi.org/10.1007/s11125-020-09464-3

Dünya Bankası (2020). The COVID-19 Pandemic: Shocks to Education and Policy Responses, https://www.worldbank.org/en/topic/education/publication/the-covid19-pandemic-shocksto-education-and-policy-responses 
Feng, Z., Xu, D., \& Zhao, H. (2007). Epidemiological models with non-exponentially distributed disease stages and applications to disease control. Bulletin of Mathematical Biology, 69(5), 1511-1536. https://doi.org/10.1007/s11538-006-9174-9

Guba, E. G., \& Lincoln, Y. S. (2005). Paradigmatic controversies, contradictions and emerging confluences. In. N. K. Denzin ve Y. S. Lincoln (Ed.). The Sage Handbook of Qualitative Research (Third Edition). (s. 191-216). Thousands Oaks, CA: SAGE Publications, Inc.

Güler, K. \& Celep, Z., (2020) IOP Conf. Ser.: Mater. Sci. Eng. 737012015.

Hargreaves, A. (2020). What's next for schools after coronavirus? Here are 5 big issues and opportunities, https://theconversation.com/whats-next-for-schools-after-coronavirus-hereare-5-big-issues-and-opportunities-135004

Huber, S.G. ve Helm, C. (2020). COVID-19 and schooling: evaluation, assessment and accountability in times of crises-reacting quickly to explore key issues for policy, practice and research with the school barometer. Educ Asse Eval Acc (2020). https://doi.org/10.1007/s11092-020-09322-y

Koh, C. G., Lee, L., Lo, C., Wong, C., \& Yap, J. (2020). A Socio-Psychological Perspective. In Challenges and Opportunities in the Post-COVID-19 World (pp. 44-48). Geneva: World Economic Forum. www.weforum.org.

Merriam, S. B., \& Tisdell, E. J. (2015). Qualitative Research: A Guide to Design and Implementation (Fourth Edition). San Fransisco, CA: Jossey Bass.

Merriam, S. B. (2009). Qualitative research. A guide to design and implementation. San Francisco: John Wiley-Sons

Miles, M. B. \& Huberman, A. M. (1994). Qualitative Data Analysis: A Sourcebook. Beverly Hills: Sage Publications

OECD (2020b). A f ramework to guide an education response to the COVID-19 Pandemic of 2020, https://oecdedutoday.com/coronavirus-education-digital-tools-for-learning/

OECD. (2020a). Education disrupted - education rebuilt: Some insights from PISA on the availability and use of digital tools for learning- OECD Education and Skills Today. https://oecdedutoday.com/coronavirus-education-digital-tools-for-learning/

Paakkari, L., ve Okan, O. (2020). COVID-19: health literacy is an underestimated problem. The Lancet Public Health, 5(5). https://doi.org/10.1016/S2468-2667(20)30086-4

Patton, M. Q. (2014). Nitel Araştırma ve Değerlendirme Yöntemleri (Çev. Ed. Bütün, M. ve Demir, S.B), Anı Yayınc1lik.

PHA. (2020). COVID-19 (Coronavirus). Public Health Agency, 18(2), 99-100. https://doi.org/10.1089//rb.2020.29084.cov

Saavedra, J. (2020). Educational challenges and opportunities of the Coronavirus (COVID-19) pandemic. https://blogs.worldbank.org/education/educational-challenges-and-opportunitiescovid-19-pandemic

Saran, S. (2020). Technology: Digital Epiphany? COVID-19 and Our Tech Futures. In Insight Report Challenges and Opportunities in the Post-COVID-19 World (pp. 24-27). Geneva: World Economic Forum. www.weforum.org.

Shenton, A. K. (2004). Strategies for ensuring trustworthiness in qualitative research projects. Education for information, 22(2), 63-75 
UNESCO (2020a). UNESCO's support: Educational response to COVID-19, https://en.unesco.org/covid19/educationresponse/consequences

UNESCO (2020b). COVID-19 crisis and curriculum: sustaining quality outcomes in the context of remote learning, Education Sector issue notes, Issue note no 4.2, https://unesdoc.unesco.org/ark:/48223/pf0000373273

UNESCO (2020c). Crisis-sensitive educational planning, Education Sector issue notes, Issue note no 2.4, https://unesdoc.unesco.org/ark:/48223/pf0000373272

Wach, E. (2013). Learning about qualitative document analysis. https://opendocs.ids.ac.uk/opendocs/bitstream/handle/20.500.12413/2989/PP\%20InBrief\% 2013\%20QDA\%20FINAL2.pdf?sequence=4.

WHO. (2020a). Covid19 Coronavirus Disease 2019 Situation Report - 72. World Health Organization (Vol. 2019). https://pers.droneemprit.id/covid19/

WHO. (2020b). Past pandemics, http://www.euro.who.int/en/health-topics/communicable diseases/influenza/pandemic-influenza/past-pandemics

Winthrop, R. (2020). Top 10 risks and opportunities for education in the face of COVID-19. https://www.brookings.edu/blog/education-plus-development/2020/04/10/top-10-risks-andopportunities-for-education-in-the-face-of-covid-19/

Yıldırım, A. \& Şimşek, H. (2013). Sosyal bilimlerde nitel araştırma yöntemleri. Ankara: Seçkin.

Yusuf, M. (2011). The impact of self-efficacy, achievement motivation, and self-regulated learning strategies on students' academic achievement. Procedia - Social and Behavioral Sciences, 15, 2623-2626. https://doi.org/10.1016/j.sbspro.2011.04.158.

Zins, J.E., Bloodworth, M.R., Weissberg, R.P. ve Walberg, H.J. (2007). The scientific base linking social and emotional learning to school success. J Educ Psychol Consult, 17: 191-210.

Paakkari, L. ve Okan, O. (2020). COVID-19: health literacy is an underestimated problem. Lancet Public Health. https://www.thelancet.com/journals/lanpub/article/PIIS24682667(20)30086-4/fulltext 